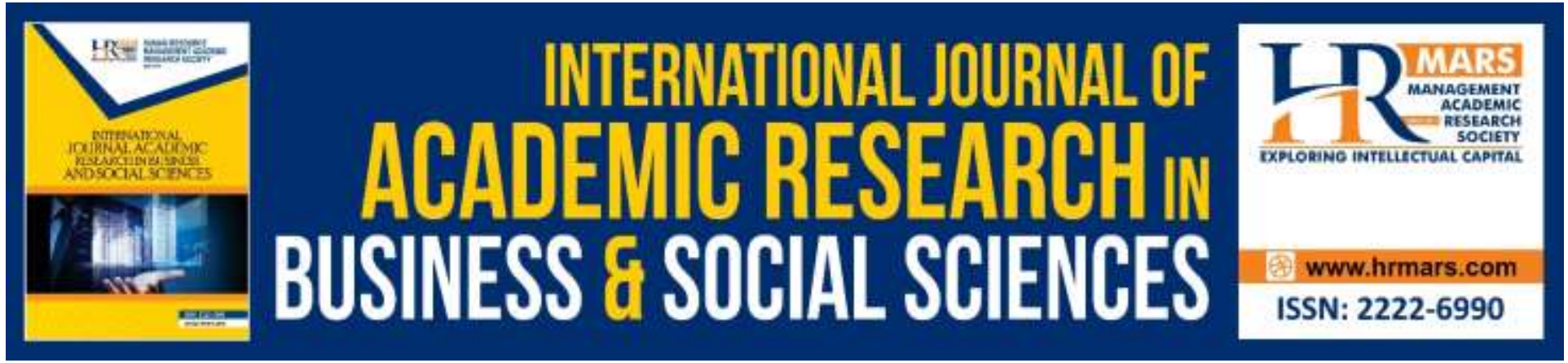

\title{
Contributions of Asnaf Entrepreneurs in Zakat of Business: A Revisiting Based on Turning over Model
}

Noormariana Mohd Din, Mohd Syakir Mohd Rosdi, Mohammad Ismail, Mohd Zulkifli Muhammad, Dzulkifli Mukhtar

To Link this Article: http://dx.doi.org/10.6007/IJARBSS/v9-i9/6366

DOI: $10.6007 /$ IJARBSS/v9-i9/6366

Received: 19 July 2019, Revised: 23 August 2019, Accepted: 05 September 2019

Published Online: 26 September 2019

In-Text Citation: (Din, Rosdi, Ismail, Muhammad, \& Mukhtar, 2019)

To Cite this Article: Din, N. M., Rosdi, M. S. M., Ismail, M., Muhammad, M. Z., \& Mukhtar, D. (2019). Contributions of Asnaf Entrepreneurs in Zakat of Business: A Revisiting Based on Turning over Model. International Journal of Academic Research in Business and Social Sciences, 9(9), 744-752.

\section{Copyright: (C) 2019 The Author(s)}

Published by Human Resource Management Academic Research Society (www.hrmars.com)

This article is published under the Creative Commons Attribution (CC BY 4.0) license. Anyone may reproduce, distribute, translate and create derivative works of this article (for both commercial and non-commercial purposes), subject to full attribution to the original publication and authors. The full terms of this license may be seen at: http://creativecommons.org/licences/by/4.0/legalcode

\section{Vol. 9, No. 9, 2019, Pg. 744 - 752}

Full Terms \& Conditions of access and use can be found at http://hrmars.com/index.php/pages/detail/publication-ethics 


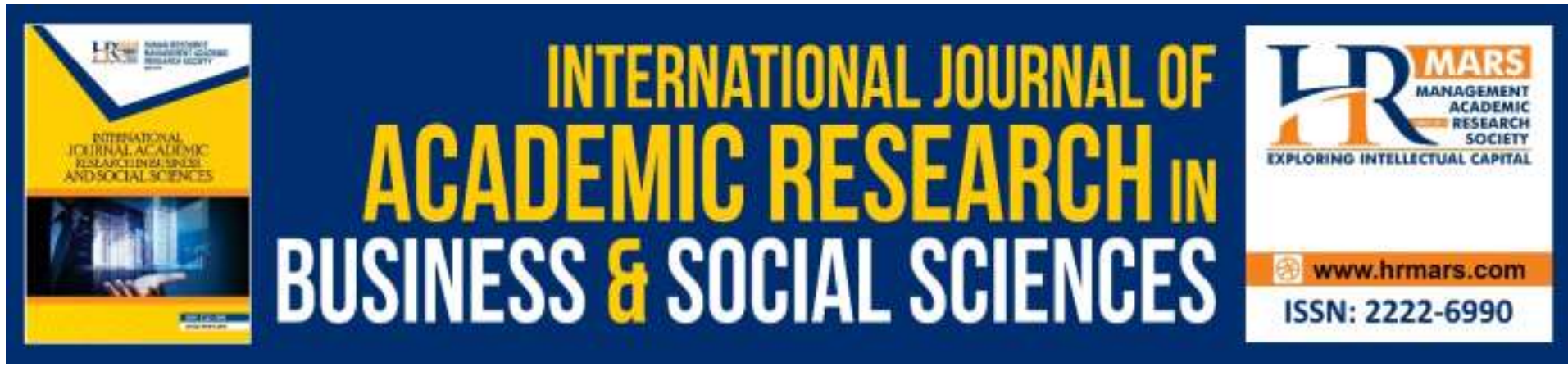

\title{
Contributions of Asnaf Entrepreneurs in Zakat of Business: A Revisiting Based on Turning over Model
}

\author{
Noormariana Mohd Din ${ }^{1}$, Mohd Syakir Mohd Rosdi², \\ Mohammad Ismail ${ }^{3}$, Mohd Zulkifli Muhammad ${ }^{4}$, Dzulkifli \\ Mukhtar ${ }^{5}$ \\ 1, 3, 4, 5 Faculty of Entrepreneurship and Business, Universiti Malaysia Kelantan \\ Malaysia, ${ }^{2 *}$ Centre for Islamic Development Management Studies (ISDEV), \\ Universiti Sains Malaysia, Pulau Pinang, Malaysia.
}

\begin{abstract}
State zakat authorities would organize the various programs in targeted towards the various Shariah ordained zakat recipients in distributing their zakat funds. Asnaf Entrepreneurial Programme (Program Usahawan Asnaf) (AEP) is one of the programs that are specifically to help the Asnaf which involved in business so that they will be able to free themselves from their current difficulty and possibly become zakat contributors themselves. However, whenever a new program related to zakat distribution is created, there is always issues concerning whether the program created beneficial to the target recipient. Therefore, aim of this paper is to revisit the model related by the contributions of Asnaf entrepreneurs in zakat of business.
\end{abstract}

Keywords: Asnaf Entrepreneurs, Zakat of Business, Turning Over Model, Contribution

\section{Introduction}

Based on the Surah At-Tawba (9:60), we can identify eight groups of society (Asnaf) to whom zakat should be distributed. They are namely, faqir, poor, amil, muallaf, fisabilillah, gharim, $i b n u$ sabil, and riqob. There are some thoughts regarding the definition of those Asnaf and their interpretation for their applications in this modern situation between some Islamic scholars. However, effectiveness issue in the distribution aiming on the poor has always been an attention specifically its impact on the economy. The purpose of the distribution of zakat in Islam is to help those in need and most importantly, to shift the poor to a successful life. Zakat institution attempts to produce an effective way for the poor to become an entrepreneur and enhancing their social and economic life under Asnaf Entrepreneurial Program (AEP). This entrepreneurial program involve with several process as stated by (Pache \& Chowdhury, 2012). The first process is identified the inputs by selecting the prospective entrepreneurs. The prospective entrepreneurs should be complying with Islamic ideas and thoughts. The second process is transformation process whereas specifically focused on the 
training and project preparation. This transformation process will be transforming the training to the outputs such as goods, services, idea and entertainment.

Finally, based on the outputs it will achieve the goals that is rapidly national growth. These processes have been applied in this paper as well it related with the support services from the government and non-government organization such as zakat institution. The entrepreneurs who are have the financial support from the various organization that owned and managed by poor people also knowns as the micro entrepreneurs or Asnaf entrepreneurs (Nadzri, Omar, \& Rahman, 2017). Zakat institution provides the capital assistance to Asnaf entrepreneurs in increasing the self-confident and productivity in business. This capital assistance is not only limited for expand the Asnaf entrepreneurs however it also gives the value for the social and morale qualities for individuals (Hazlina Abdul, Said, \& Yusuf, 2012). Apart from the positive contribution in economy and social, the support from the government and non-government towards Asnaf entrepreneurs is important. As matter of fact, it encourages directly the positive boost up zakat collection through Asnaf entrepreneurs based on the Turning Over Model.

\section{Asnaf Entrepreneurial Program (AEP) (Program Usahawan Asnaf)}

Zakat is the way of distribute among people in the following categories (Surah At Taubah, 9:60), depending on the need such as destitute, poor, zakat workers (Amil), new Muslim (Muaallaf), to free slaves, the indebted, in the path of Allah and stranded traveller. Considering these categories, the zakat institution produces the effective way for these categories to enhance the better life in social and economic under Asnaf Entrepreneurial Programme (AEP). This group will be given help and attention solely by certain parties for such purposes. This is because, this group are unable to move on its own given the lack of suffered financial (Balwi \& Halim, 2008). Therefore, Zakat institution collaborate with Institut Keusahawanan Negara (INSKEN) and Institut Latihan Islam Malaysia (ILIM) in monitoring the knowledge and skill among entrepreneurs. Purpose of the programme designed for the poorest Muslim group in Malaysia and fully supported by the zakat institutions based on the Asnaf Entrepreneur Development Model by Mohd Abd Wahab Fatoni and Halim (2008) such as exposure, education, implementation, marketing, monitoring, knowledge, oriented planning, the religious and consultation. Based on the elements in model, it is developed the functions of mobilizing zakat in developing entrepreneurships among Asnaf as well as based on an entrepreneur's development process mode for zakat distribution.

Therefore, it achieved social and economic development, some of zakat institution in Malaysia concern in develop the entrepreneur among Asnaf such as Lembaga Zakat Selangor (MAIS) and Majlis Agama Islam Kelantan (MAIK). For instance, MAIS succeed distributed the mobile business to 45,000 Asnaf under entrepreneurial program (Asnaf MAIS, 2015). This program has produced a successful entrepreneur in the retail, service, fast food providers and fishermen. During the establishment of this program, it proved to withdraw the charity of poverty with an income of about RM 9,000 to RM 30,000 per month. Through this revenue supported under this program, it has incubated more producers' recipients of zakat in helping others in the field of entrepreneurship (Asnaf MAIS, 2015; Maheran, 2014; Lembaga Zakat Selangor, 2013). In 2015, zakat institutions supported around RM 9,000,0000 to Asnaf who are under this programme covered in terms of training, capital and facilities to become entrepreneurs (Asnaf MAIS, 2015). The paradigm of Asnaf change to Asnaf entrepreneurs through zakat assets and the duties of Asnaf limited focused by other studies. The 
entrepreneurship activities aimed providing in generating income and entrepreneurial character by creating the positive values for Asnaf entrepreneur's in generating additional income. The implementation of Asnaf entrepreneurs is illustrated by zakah institutions.

\section{Revisiting Turning Over Model}

The implementation of Asnaf entrepreneurs is illustrated by zakah institutions as refer Figure 1 below known as "Turning Over Model" which are basically zakat distributed to potential Asnaf in business (Sabri \& Hasan, 2006). Then, Asnaf undergoes the process of forming and enhancing the business with the aid of zakat and is monitored by zakat institution. Through this business assistance, it also gives Asnaf an opportunity to work and earn a better income. It can also prevent the Asnaf from relying on zakat funds without self-determination as well Rasulullah SAW. In an expression of his advice as follows:

"And say: "Take (your duty), so Allah, His Messenger, and those who believe will see what you do. and you will be returned to (Allah) Who knows the Unseen and the Unseen, and then it will explain to you what you did" (Muttafaqun alaih).

It is in accordance with the will of Allah SWT as in Surah al-Taubah: 105, which explains Allah SWT never wasting any work done by Muslims and always given attention by Allah SWT and his Prophet. It encompasses aspects of jihad fi sabillah and self-involvement in seeking livelihood and further encouraging other believers. However, this concept is less exposed because the understanding of society towards the main objectives of established entrepreneurs is still weak. Hence, this paper revisiting the concept of Turning Over Model as well as it is presenting the contribution of Asnaf Entrepreneurs towards zakat on business. 


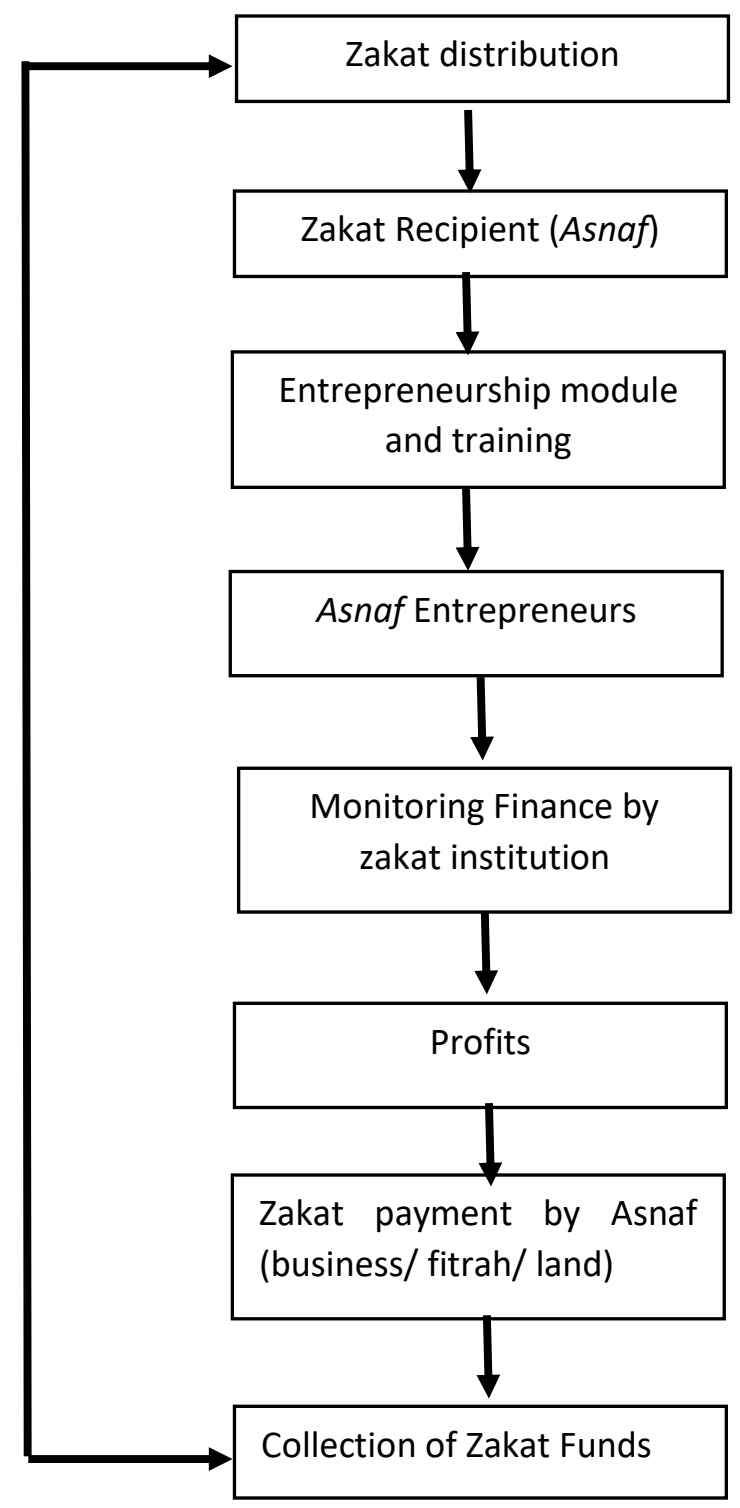

Figure 1: Turning Over Model

\section{Contributions of Asnaf Entrepreneurs in Zakat of Business}

The concept of contribution generally it depends on the person's behaviour or action. this behaviour basically involve in the process of learning by some external environment factors (Pachauri, 2002). This model presented the integrating factors to support the behavioural such as knowledge and skills, salience of the behaviour, intention or decision to perform the behaviour and habit. However, these factors depend on the attitude, perceived norm and personal agency by individual (Battistich, Schaps, Watson, Solomon, \& Lewis, 2000). Based on the field of this model, it suitable to support this paper as well as it also occurs as the individual learns to perform behaviour that produce positive outcomes and to avoid those that yield negative outcomes as suggested by (Battistich, et al., 2000). This behaviour concern with the individual compliance. 
Thus, this paper revisits the concept of Asnaf entrepreneur's contribution towards zakat on business by relates the compliance behaviour. The compliance behaviour issue have been explored by several researcher especially in collection of taxation. In Islamic taxation, the issue of zakat on business is supported by the individual's compliance behaviour which plays the main role in the zakat collection on business. Only $2.5 \%$ of every business profit is collected as zakat. Nonetheless, it is considered as a burden in carrying out the duties of the zakat payers (Awang, 2007; Hairunnizam, 2017). By relating with Turning Over Model, is to enable Asnaf entrepreneurs to contribute zakat on business after becoming entrepreneurs. However, it lacks to review by past studies as well it only focused on the Asnaf entrepreneur's success.

\section{Entrepreneur and Social Economic Development Based on Turning Over Model}

Entrepreneurs are regarded as innovators in the economic development. The economic performance in the country highly depends on the successful entrepreneurs as well as stable in the activity. By realize the important of entrepreneurship therefore this study focusing the entrepreneur's compliance behaviour as predictor the step and decision making in the evolving and long-term process. Previously, many researchers interested explored by underlying assumptions of the theory planned behaviour (TPB) and related with entrepreneurship such as (Farkas \& Gubik, 2013; Lu \& Chen, 2013; Choy, Kuppusamy, \& Jusoh, 2005).

By indicate the importance of efficient collection of zakat to ensure socio-economic objectives of zakat, it relatively effect on aggregated consumption. For instance, if the income totally for the consumption and spending for the cause of Allah, this will increase the overall consumption and saving for Hereafter (Wahab \& Rahman, 2011).

In wealth creation mechanism, this study had focused on the businesses mechanism to review and indicate the payment of zakat. According Rahim and Md (2011), showed that the percentage of zakat payer among Muslim business community is still at a small rate as compared with the total number of business based on Companies Commission of Malaysia. The lack of motivation among Muslim business to pay the zakat, as a result this scenario closely related and need investigated depend on compliance behavior of zakat on business (Hussin, Muhammad, \& Ahmad, 2013). In Kelantan Malaysia, such as, it found that the aims payment of zakat among batik entrepreneur is low compare with the amount of profit in batik entrepreneur (Norazmalinda, 2011). In entrepreneurship perspective, even it presented the higher of business registered with Companies Commission of Malaysia but the percentage of zakat payer among Muslim is still at a small rate. Number of Business registers 332, 723 and 19 percent Muslim business presented 63,217 (Companies Commission of Malaysia, 2014). Inopportunely only 3.5 percent among of them pay zakat on business. Although a variety of efforts by government and financial institution have implement towards development of entrepreneur but it still happened (Zamberi \& Siri, 2012).

In Islamic views, entrepreneurship covered the supportive and motivational activities. These activities as refers such as risk taking, innovativeness, excellence and social welfare according with Islamic entrepreneurship development (IEDM) (Nazamul, 2014). Consequently, under Islamic social finance it refers the zakat as the one of mechanism for development in the social and economic (Al-Banna \& Michael, 2015). Under Islamic social finance, it presented the zakah, sadaqah and qard al-Hassan as an alternative used to support the business in addition to some of facilities in Islamic banking (Necati, 2015). This research 
framework is based on the combination of Theory Planned Behaviour (TPB) (Ajzen, 1991) and Giving Back Theory (Kane, 1987) based on turning over model. The following is the conceptual framework:

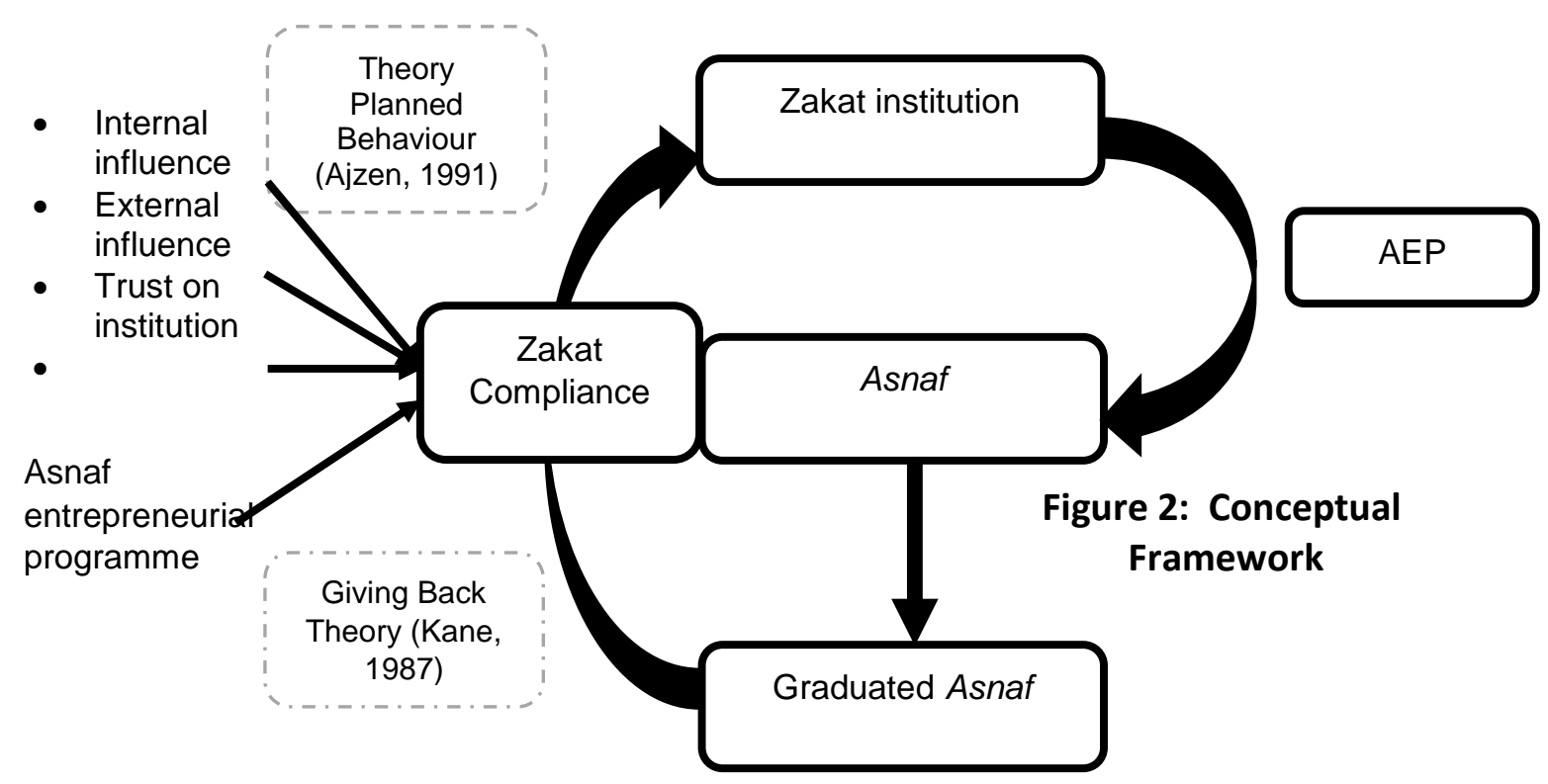

\section{Contributions of Asnaf Entrepreneurs Towards Zakat Collection Based on Turning Over Model}

Nevertheless, in an effort to move towards economic and social justice by year 2020, the eradication of poverty continues to be one of the key agenda areas national developments (Sulochana, 2001). Those people who are no capable and marginalized groups will continue to receive their rights to ensure that their lives are more secure in the pursuit of a society that has a fair chance of reducing racial issues and economic imbalances (Reisch, 2002). The poor can apply for zakat assistance to get the capital to start a business. Therefore, successful Asnaf entrepreneurs will contribute to the MAIK. Then, donations received by MAIK will be donated to new Asnaf entrepreneurs. Through the successful contribution of Asnaf entrepreneurs can increase the revenue of zakat collections from MAIK. Hence, the process of new Asnaf application will be easier and faster and the percentage for MAIK rejects the applicant is low. In addition, successful Asnaf entrepreneurs can provide guidance to new Asnaf entrepreneurs to start their business and motivate new Asnaf groups. This can give a little more knowledge to new applicants to run their business.

Through the program of Asnaf entrepreneurs, fakir, poor Asnaf and muallaf who are skilled in entrepreneurship are given capital assistance to start their business or expand their micro business that is ready for them (Raflis et. al. '2012). Capitalization is expected to generate long-term income and help transform them into entrepreneurs and subsequently change from zakat recipients to zakat payers (Rosbi \& SInep, 2011). Other than that, Rosbi \& Sanep (2011) also think that this entrepreneurial program is a mechanism and is considered the best way to eradicate Asnaf poverty. The selected Asnaf will be identified and potential to be featured as an entrepreneur. 
Social business operates as a business enterprise, by providing products, services, customers, markets, and income but the principle of maximizing profitability is replaced by social benefit principles to achieve social marketing. Social business models will have a positive impact on the Asnaf through the assistance of zakat capital. This is because of social business has a link between the micro credit and Amanah Ikhtiar Malaysia (AIM) financing instruments. Therefore, social business is expected to revive the Asnaf economy and produce the personality of the Asnaf and increase the piety in their souls (Najwa, Hairunnizam \& Sanep, 2013).

\section{Conclusion}

In conclusion, the accountability in the zakat fund management is driven by the Islamic foundation, which cannot be separated from the Islamic teachings and pathways. For this reason, the zakat contribution in turning over model is essential, which all the Muslims have to abide by, through the shadowing of the intangible relations within the human being, Muslims and submission to Allah. This relation is unseparated, which the social action is constructed in the social reality within the social practice of individual and their accountability to Allah as: "And I did not create the jinn and mankind except to worship Me" (Chapter AzZariyat: Verse No 56).

\section{Acknowledgement}

This paper was supported by the SGJP (INSPEK) grant (2018) titled: Modelling of successful Asnaf entrepreneur's towards poverty alleviation. The authors are indebted to the prior literature research that has been made in various anonymous journal/conference references related to zakat and Asnaf field.

\section{Corresponding Author}

Dr. Mohd Syakir Mohd Rosdi

Senior Lecturer

Center for Islamic Development Management Studies (ISDEV)

Universiti Sains Malaysia,

Penang, Malaysia.

Email: mohdsyakirmohdrosdi@gmail.com/mohdsyakir@usm.my

\section{References}

Rahman, A. A. (2014). Memformulasi model produktif pembangunan program usahawan bagi memperkasakan ekonomi golongan Asnaf. Paper presented at the Persidangan Kebangsaan Ekonomi Malaysia ke-9 (PERKEM ke-9), Kuala Terengganu, Terengganu.

Muhamat, N. J. A. A., Rosly, H. E. \& Manan, H. A. (2013). An appraisal on the business success of entrepreneurial Asnaf: An empirical study on the state zakat organization (the Selangor Zakat Board or Lembaga Zakat Selangor) in Malaysia. Journal of Financial Reporting and Accounting, 11(1), 51-63.

Asnaf MAIS. (2015). Bersama kami membantu Asnaf. Selangor: Lembaga Zakat Selangor.

Balwi, M. A. W. F. M., \& Halim, A. H. A. (2008). Mobilisasi zakat dalam pewujudan usahawan Asnaf: Satu tinjauan. Jurnal Syariah, 16(Keluaran Khas), 567-584. 
Farley, S. D., \& Stasson, M. F. (2003). Relative influences of affect and cognition on behavior: Are feelings more related to blood donation intentions? Experimental Psychology, 50(1), 55.

Salwa, A. F., \& Borhan, J. T. (2014). Faktor-faktor kejayaan perniagaan Khadijah binti Khuwailid: Analisis terhadap usahawan Asnaf di Lembaga Zakat Selangor. Jurnal Syariah, 21(2).

Mastura, F. N. A., \& Bidin, Z. (2013). Zakat compliance intention behavior on saving. Paper presented at the Proceedings of World Universities's Islamic Philanthropy Confence 2013, Kuala Lumpur, Malaysia.

Mastura, F. Z. B. (2015). Determinants of attitude toward zakat on saving. Australian Journal of Basic and Applied Sciences, 9(31), 7-13

Abdul, H., Said, J., \& Yusuf, S. N. S. (2012). Individual characteristics of the successful Asnaf entrepreneurs: Opportunities and solutions for zakat organization in Malaysia. International Business and Management, 4(2), 41-49.

Wahid, H., S. A., \& Kadir, R. A. (2010). Pengagihan zakat oleh institusi zakat kepada 8 Asnaf: Kajian di Malaysia. Jurnal Pengurusan JAWHAR, 4(10), 141.

Hairunnizam, A. S., \& Noor, M. A. M. (2004). Kesan bantuan zakah terhadap kualiti hidup Asnaf fakir dan miskin. Paper presented at the Proceedings National Seminar in Islamic Banking and Finance (iBAF), Kolej Universiti Islam Malaysia, Bandar Seri Putra, Kajang, Selangor.

Lu, W. C., \& Chen, W. H. (2013). A study on female entrepreneurs' behavior in microenterprises in Taiwan: An application of planned behavior theory. Journal of Global Business Management, 9(1), 204-219. 